Article

\title{
Effect of Cdx2 Polymorphism on the Relationship between Dietary Calcium Intake and Peak Bone Mass in Young Japanese Women
}

\author{
Fumi Oono ${ }^{1,+}$, Yuri Sakamoto ${ }^{2,+}$, Yoichi Tachi ${ }^{2}$, Hideaki Mabashi-Asazuma ${ }^{1}$ (D) \\ and Kaoruko Iida $1,3, * \mathbb{D}$ \\ 1 Department of Nutrition and Food Science, Graduate School of Humanities and Sciences, Ochanomizu \\ University, Tokyo 112-8610, Japan; g1940518@edu.cc.ocha.ac.jp (F.O.); mabashi.hideaki@ocha.ac.jp (H.M.-A.) \\ 2 Laboratory of Nutrition Physiology, Tokyo Kasei University, Tokyo 173-8602, Japan; \\ sakamoto-y@tokyo-kasei.ac.jp (Y.S.); tachi@tokyo-kasei.ac.jp (Y.T.) \\ 3 Institute for Human Life Innovation, Ochanomizu University, Tokyo 112-8610, Japan \\ * Correspondence: iida.kaoruko@ocha.ac.jp; Tel.: +81-3-5978-5474 \\ + These authors contributed equally to this work.
}

Received: 6 December 2019; Accepted: 8 January 2020; Published: 10 January 2020

\begin{abstract}
Studies investigating the effect of the caudal-type homeobox protein $2(\mathrm{Cdx} 2)$ polymorphism in the vitamin D receptor gene and calcium intake on bone mass have shown inconsistent results. This study investigated whether the effect of calcium intake on peak bone mass is affected by $\mathrm{Cdx} 2$ polymorphism in young Japanese women. A cross-sectional study of 500 young women was conducted. Dietary intake was assessed by the Food Frequency Questionnaire. The osteo sono-assessment index (OSI), assessed by the qualitative ultrasound method, was used as a bone mass index. The subjects were divided into two groups by the median calcium intake. The OSI was not different among Cdx2 genotypes and between calcium groups ( $p=0.960, p=0.191$, respectively). The interaction between calcium and Cdx2 genotypes on the OSI approached significance (GG versus GA and AA genotypes, $p=0.092$ ). The difference in the OSI between calcium groups was significant in the GG genotype ( $p=0.028)$, but not in the GA or AA genotypes $(p=0.501, p=0.306$, respectively). Adjustment for covariates (body mass index and physical activity) did not change the results. In conclusion, the relationship between dietary calcium intake and peak bone mass may vary according to $\mathrm{Cdx} 2$ polymorphism.
\end{abstract}

Keywords: vitamin D receptor gene; Cdx2 polymorphism; bone mass; premenopausal women; calcium consumption

\section{Introduction}

Osteoporosis is becoming a major public health problem worldwide, particularly in the aging community. Women, specifically, have a high risk of developing osteoporosis because of a lower peak bone mass than men [1] and a sharp decrease in bone mass after menopause [2]. In addition to preventing bone loss during aging, increasing the peak bone mass at a younger age is also important for the prevention of osteoporosis and reducing the risk of fracture [3].

Determinants of peak bone mass include lifestyle factors, such as physical activity $[4,5]$ and calcium intake $[4,6]$, as well as genetics $[6,7]$. Calcium intake is widely accepted as an important nutritional factor for increasing peak bone mass, and the national osteoporosis foundation regards calcium intake as the best grade of evidence for increasing peak bone mass [4]. However, the relationship between dietary calcium intake and bone mass (or density) is obscure [8-10]. The potential interactions between calcium intake and genetics, such as the vitamin D receptor (VDR) polymorphism on bone mass, 
have been reported during the last few decades [11,12], and Eisman [11] suggested the necessity of personalizing nutritional recommendations according to each genotype.

The caudal-type homeobox protein $2(\mathrm{Cd} 2)$ polymorphism would be important among VDR polymorphisms because it is located in the promoter region of the VDR gene and a previous study reported that $\mathrm{A}$ allele relates to higher promoter activity in vitro [13]. However, the results of studies focusing on the interaction of the $\mathrm{Cdx} 2$ polymorphism and calcium intake on bone mass (or density) are inconsistent [14-17]. The inconsistency can be partly explained by the difference in study populations. Genotype frequencies, linked genes, environmental factors, and dietary factors are different among studies. Uitterlinden et al. [18] suggested that different populations can have different gene-environment interactions. With regard to premenopausal women, only two studies have investigated the effect of the Cdx2 polymorphism and calcium intake on bone mass [15,17]; one focused on girls in the adolescence stage before reaching peak bone mass (12.3-17.9 years old) [15], and the other on women over a wide range of age (20-54 years old) [17]. This age heterogeneity might lead to unclear results because menarcheal status, experience in delivery, and the effects of other lifestyle factors (e.g., smoking, alcohol intake, and physical activity) would vary in such a diverse population.

We, therefore, conducted a cross-sectional study among young women, whose bone mass was considered to be stable, to investigate the effect of $\mathrm{Cdx} 2$ genotypes on the relationship between dietary calcium intake and peak bone mass.

\section{Materials and Methods}

\subsection{Study Population}

The subjects were 555 female college and junior college students aged 20-24 years old, who were recruited between 2015 and 2019. Written informed consent was obtained from all subjects. The study was conducted in accordance with the Declaration of Helsinki, and the study was approved by the ethics committee of Tokyo Kasei University (approval number: ITAH26-04).

We excluded the following subjects from analysis: those who received obstetrics treatment such as estrogen or steroid hormone therapy $(n=42)$, those who had missing data $(n=9)$, and those who reported a daily energy intake less than half of their required energy intake $(n=4)$ or more than 1.5 times their required energy intake $(n=0)$. Required energy intake was determined according to the Japanese Dietary Reference Intake 2015 [19] using the medium physical activity category and the individual age, height, and weight. Overall, 500 subjects were included in the analysis.

\subsection{Dietary Assessment}

Dietary intake was assessed using a Food Frequency Questionnaire based on food groups (FFQg) Ver.3.0, which consists of questions about 29 food groups and 10 types of cooking to estimate energy and nutrient intake during the past 1-2 months [20,21]. Excel add-in software (Excel Eiyou-kun, Kenpakusha Co. Ltd., Tokyo, Japan) was used to analyze the data. Daily energy and calcium intake estimated by the FFQg significantly correlated to that estimated by 7-days weighed dietary records $(r=0.465,0.410$, respectively) $[20,21]$.

\subsection{Genotyping}

Genomic DNA was extracted from saliva using an Orange ${ }^{\circledR}$ DNA extraction kit (DNA Genotek Co Inc., Ottawa, OT, Canada) according to the manufacturer's protocol. Extracted DNA was diluted to a concentration of less than $100 \mathrm{ng} / \mu \mathrm{L}$ and stored at $-20{ }^{\circ} \mathrm{C}$.

Genotypes were detected by real-time polymerase chain reaction (PCR) using the Thermal Cycler Dice ${ }^{\circledR}$ Real Time System (TaKaRa Bio Inc, Shiga, Japan). The Cdx2 polymorphism (rs11568820) was assessed using the following primers: 5'-AAGGAAAGAAAGAAAGGAAG-3' (forward) and 5'-GGTCTTCCCAGGACAGTAT-3' (reverse), and the probes: FAM-(Eclipse)AGGTCACArGTA and ROX-(Eclipse)GGTCACArATAA. The reaction mixture contained $12.5 \mu$ L Cycleave PCR Reaction Mix 
(2×) (TaKaRa Bio, Shiga, Japan), $0.5 \mu \mathrm{L}$ of each primer $(10 \mu \mathrm{M}), 0.1 \mu \mathrm{L}$ of each probe $(50 \mu \mathrm{M}), 1.0 \mu \mathrm{L}$ sample DNA, and $11.3 \mu \mathrm{L}$ water. PCR was performed under the following conditions: $95^{\circ} \mathrm{C}$ for $10 \mathrm{~s}$ and then 50 cycles of amplification $\left(95^{\circ} \mathrm{C}\right.$ for $5 \mathrm{~s}, 55^{\circ} \mathrm{C}$ for $10 \mathrm{~s}$, and $72{ }^{\circ} \mathrm{C}$ for $20 \mathrm{~s}$ ).

\subsection{Measurement of Calcaneal Bone Mass}

Calcaneus bone mass was assessed using the quantitative ultrasound (QUS) method on the right calcaneus using an AOS-100SA system (Hitachi Co. Ltd., Tokyo, Japan). The previous reports showed that QUS measurements are significantly correlated with bone mineral density assessed by dual-energy X-ray absorptiometry (DXA, $r=0.804, p<0.001$ ) [22], and are able to predict the risk of fracture [23,24].

We used the osteo sono-assessment index (OSI) as an index of calcaneus bone mass. The OSI was obtained from the transmission index (TI) and the speed of sound (SOS) using the following formula: OSI $=\mathrm{TI} \times \mathrm{SOS}^{2}$. OSI is highly reproducible [25]. All OSI values presented in this paper were divided by $10^{6}$.

\subsection{Assessment of Other Variables}

As a previous study reported that physical activity in junior high school strongly affects peak bone mass [26], participants were required to complete a self-administered questionnaire regarding their physical activity habits in junior high school. Physical activity habits were defined as exercise habits other than physical education class and subjects were asked what type of sports they undertook in each period. Height and weight were also obtained by self-administered questionnaire, and then, body mass index (BMI) $\left(\mathrm{kg} / \mathrm{m}^{2}\right)$ was calculated by dividing the weight by the square of the height.

\subsection{Statistical Analysis}

All statistical analyses were performed using SPSS version 24 software (SPSS Inc, Chicago, IL, USA). Accordance with Hardy-Weinberg's equilibrium was assessed using $\chi^{2}$ tests. Calcium intake was adjusted for daily energy intake using the density method. The value obtained from the density method was converted to an integer. The subjects were divided into two groups by the median calcium intake.

To determine the difference in characteristics based on genotypes and calcium intake groups, analysis of variance (ANOVA) and independent-samples $t$-test were employed, respectively. $\chi^{2}$ tests were used for categorical variables (i.e., physical activity habits). Analysis of covariance (ANCOVA) was used to examine differences in the OSI among $\mathrm{Cdx} 2$ genotypes or between calcium intake groups adjusted by covariates; the covariates were BMI $\left(\mathrm{kg} / \mathrm{m}^{2}\right.$, continuous) and physical activity habits in junior high school (yes or no).

The relationship between genotypes and calcium intake on the OSI was evaluated by two-way ANOVA and adjusted with the above-mentioned covariates. To assess the effect of calcium intake on OSI based on Cdx2 genotypes, we separated subjects according to Cdx2 genotypes and used ANCOVA. All reported $p$ values were two-tailed, and $p<0.05$ was considered significant.

\section{Results}

The basic characteristics of the subjects are shown in Table 1. All subjects were female and the mean value of the OSI was 2.72 .

The genotype frequency (Table 2) was in the Hardy-Weinberg equilibrium $(p=0.163)$. There were no significant differences in all variables among Cdx2 genotypes. The OSI among the three genotype groups showed no significant difference when adjusted with the covariates (BMI and physical activity habits in junior high school) $(p=0.648)$. 
Table 1. Characteristics of participants in this study $(n=500)$.

\begin{tabular}{cc}
\hline Variable & Value \\
\hline Age (years) & $20.0 \pm 0.3$ \\
Height $(\mathrm{cm})$ & $158.7 \pm 5.3$ \\
Weight $(\mathrm{kg})$ & $51.4 \pm 6.0$ \\
BMI $\left(\mathrm{kg} / \mathrm{m}^{2}\right)$ & $20.4 \pm 2.0$ \\
OSI & $2.72 \pm 0.26$ \\
Energy (kcal/day) & $1723 \pm 388$ \\
Calcium (mg/day) & $456 \pm 169$ \\
Calcium (mg/1000 kcal) & $263 \pm 69$ \\
Physical activity habits in junior high school (\%) & 66.6 \\
\hline
\end{tabular}

Values are means \pm standard deviation or percentage. Abbreviations: BMI, body mass index; OSI, osteo sono-assessment index.

Table 2. Characteristics of participants compared to caudal-type homeobox protein $2(\mathrm{Cdx} 2)$ genotyping.

\begin{tabular}{ccccc}
\hline & \multicolumn{3}{c}{ Cdx2 } & \multirow{2}{*}{$p$} \\
\cline { 2 - 4 } & GG & GA & AA & \\
\hline Number $(\%)$ & $159(31.8)$ & $264(52.8)$ & $77(15.7)$ & - \\
Age (years) & $20.0 \pm 0.1$ & $20.1 \pm 0.4$ & $20.0 \pm 0.2$ & 0.125 \\
Height $(\mathrm{cm})$ & $158.3 \pm 5.7$ & $159.0 \pm 5.1$ & $158.2 \pm 5.2$ & 0.242 \\
Weight $(\mathrm{kg})$ & $51.2 \pm 6.1$ & $51.4 \pm 5.9$ & $52.0 \pm 6.1$ & 0.669 \\
BMI $\left(\mathrm{kg} / \mathrm{m}^{2}\right)$ & $20.4 \pm 2.0$ & $20.3 \pm 2.1$ & $20.7 \pm 2.0$ & 0.248 \\
OSI & $2.72 \pm 0.25$ & $2.71 \pm 0.27$ & $2.71 \pm 0.26$ & 0.960 \\
Calcium (mg/1000 kcal) & $259 \pm 66$ & $266 \pm 72$ & $261 \pm 64$ & 0.579 \\
Physical activity habits in junior high school $(\%)$ & 62.9 & 67.4 & 71.4 & 0.393 \\
\hline
\end{tabular}

Values are means \pm standard deviation or percentage. The $p$ values are the level of significance of difference based on genotypes. The $p$ values of continuous variables were assessed by analysis of variance (ANOVA) and the $p$ values of physical activity habits were assessed by the $\chi^{2}$ test. Abbreviations are the same as in Table 1 .

As the median calcium intake among our subjects was $250 \mathrm{mg} / 1000 \mathrm{kcal}$, the subjects were assigned to either the low group ( $\leqq 250 \mathrm{mg} / 1000 \mathrm{kcal})$ or the high group $(\geqq 251 \mathrm{mg} / 1000 \mathrm{kcal})$. The characteristics of each group are shown in Table 3. There was no significant difference in all variables between calcium groups. The OSI between calcium groups showed no significant difference even after adjustment with the covariates $(p=0.320)$.

Table 3. Characteristics of participants compared to dietary calcium intake (mg/1000 kcal).

\begin{tabular}{cccc}
\hline & \multicolumn{2}{c}{ Dietary Calcium Intake } & \multirow{2}{*}{$p$} \\
\cline { 2 - 3 } & Low $(\boldsymbol{n = 2 4 8 )}$ & High $(\boldsymbol{n = 2 5 2})$ & \\
\hline Calcium $(\mathrm{mg} / 1000 \mathrm{kcal})$ & $211 \pm 28$ & $314 \pm 58$ & - \\
Age (years) & $20.0 \pm 0.2$ & $20.1 \pm 0.4$ & 0.103 \\
Height $(\mathrm{cm})$ & $158.5 \pm 5.6$ & $158.8 \pm 5.1$ & 0.546 \\
Weight $(\mathrm{kg})$ & $51.2 \pm 6.2$ & $51.7 \pm 5.8$ & 0.351 \\
BMI (kg/m $\left.{ }^{2}\right)$ & $20.4 \pm 2.1$ & $20.5 \pm 1.9$ & 0.500 \\
OSI & $2.70 \pm 0.27$ & $2.73 \pm 0.25$ & 0.191 \\
Energy (kcal/day) & $1695 \pm 384$ & $1752 \pm 390$ & 0.101 \\
Physical activity habits in junior high school $(\%)$ & 64.9 & 68.3 & 0.449 \\
\hline
\end{tabular}

Values are means \pm standard deviation. The $p$ values are the level of significance of difference based on dietary calcium intake. The $p$ values of continuous variables were assessed by an independent-samples $t$-test and the $p$ values of physical activity habits were assessed by the $\chi^{2}$ test. Abbreviations are the same as in Table 1 .

The interaction between calcium intake and $\mathrm{Cdx} 2$ genotype showed a tendency of significance ( $p=0.092$ and $p=0.079$, not adjusted and adjusted, respectively) (GG versus carriers of mutant type A gene). The difference in the OSI between calcium intake groups was significant for the GG genotype 
( $p=0.028)$, but not for the GA or AA genotypes ( $p=0.501, p=0.306$, respectively). Adjustment for covariates did not change the results (Table 4 ).

Table 4. Difference in OSI between calcium intake groups based on Cdx2 genotypes.

\begin{tabular}{|c|c|c|c|c|c|c|}
\hline \multirow{2}{*}{ Cdx2 Genotypes } & \multirow{2}{*}{ Calcium Intake } & \multirow{2}{*}{$n$} & \multicolumn{2}{|c|}{ Not Adjusted } & \multicolumn{2}{|c|}{ Adjusted ${ }^{\dagger}$} \\
\hline & & & OSI & $p$ & OSI & $p$ \\
\hline \multirow{2}{*}{ GG } & Low & 81 & $2.68 \pm 0.03$ & \multirow{2}{*}{$0.028 *$} & $2.68 \pm 0.03$ & \multirow{2}{*}{$0.047^{*}$} \\
\hline & High & 78 & $2.76 \pm 0.03$ & & $2.76 \pm 0.03$ & \\
\hline \multirow{2}{*}{ GA } & Low & 127 & $2.70 \pm 0.02$ & \multirow{2}{*}{0.501} & $2.71 \pm 0.02$ & \multirow{2}{*}{0.760} \\
\hline & High & 137 & $2.72 \pm 0.02$ & & $2.72 \pm 0.02$ & \\
\hline \multirow{2}{*}{ AA } & Low & 40 & $2.74 \pm 0.04$ & \multirow{2}{*}{0.306} & $2.74 \pm 0.04$ & \multirow{2}{*}{0.248} \\
\hline & High & 37 & $2.68 \pm 0.04$ & & $2.68 \pm 0.04$ & \\
\hline
\end{tabular}

Values are means \pm standard error. The $p$ values are the level of significance of difference in the OSI between dietary calcium intake groups. Analysis was performed using analysis of covariance (ANCOVA). ${ }^{\dagger}$ adjusted for BMI and physical activity habits in junior high school. ${ }^{*} p<0.05$.

\section{Discussion}

In young females, after achieving peak bone mass of the calcaneus [27], we found that the relationship between calcium intake and peak bone mass differed among $\mathrm{Cdx} 2$ genotype groups.

The Cdx2 polymorphism did not affect bone mass in this study. The genotype frequency in this study was in accordance with those of the Hardy-Weinberg equilibrium and previous studies involving Japanese participants $[13,17]$. While many studies have not demonstrated a relationship between the $C \mathrm{~d} \times 2$ polymorphism and bone mineral density $[13,14,16,17,28-35]$, some have identified relationships [36,37]. This inconsistency might be due to relatively small study sample sizes or a wide range of age. When we focused on the studies only among premenopausal females, they showed that bone mineral density did not differ according to Cdx2 genotype [13,17,29].

Mean OSI values did not differ between dietary calcium intake groups. While previous studies have reported a significant relationship between calcium intake and bone mineral density at several bone sites in young females [38-42], some of them found no significant relationship at other bone sites [40-42]. Moreover, Correa-Rodríguez $\mathrm{M}$ et al. [43] suggested that the calcaneus was more affected by physical activity than nutrient intake; here, the OSI was affected by the physical activity habits in junior high school (data not shown). Therefore, a possible explanation for the result of no relationship between calcium intake and the OSI is that a very weak (or null) effect of calcium intake on calcaneal peak bone mass was masked by physical activity and other covariates.

However, upon division of the subjects according to Cdx2 polymorphism genotype, the effect of calcium intake on bone mass became obvious. We found that subjects with higher calcium intake had approximately $3 \%$ higher peak bone mass than those with lower calcium intake, only in subjects with the GG genotype. Hernandez et al. [44] suggested that a 10\% increase in peak bone mass is predicted to delay the onset of osteoporosis by more than ten years. Therefore, the increase in GG subjects would be expected to delay the onset of osteoporosis by a few years.

Consistent with our results, Morita et al. [17] reported that higher milk intake relates to higher bone mineral density only in the GG genotype among premenopausal Japanese women. However, a study among European children showed that there was no interaction between calcium intake and Cdx2 polymorphism on bone mineral density [15]. This disparity is partly because of the small number $(n=117)$ and younger age (mean age: 14.9 years old) of subjects in the study [15].

Mechanistically, Arai et al. [13] showed that the A allele of $\mathrm{Cdx} 2$ has a higher transcriptional activity of VDR than the G allele in vitro. To our knowledge, however, there is no experimental study investigating whether the $\mathrm{Cdx} 2$ polymorphism affects calcium absorption, despite it having been investigated for other VDR polymorphisms (BsmI, TaqI, and ApaI) using dual stable isotopes [45,46]. It was reported that the $\mathrm{Cdx} 2$ polymorphism modified the positive association between calcium intake 
and prostate cancer risk in White [47] and African American [48] people. Therefore, there is a possibility that the $\mathrm{Cdx} 2$ polymorphism changes calcium metabolism according to the amount of calcium intake.

One of the advantages of this study was that the age range of subjects was very narrow ( $20 \pm 0.3$ years old) and $97 \%$ of subjects ( $n=486$ ) were 20 years old. Therefore, we were able to reduce the effect of factors affecting peak bone mass (e.g., alcohol intake, smoking, and reproductive history) because alcohol intake and smoking by people under 20 years old are prohibited by law in Japan. Moreover, a previous study showed that alcohol intake, smoking, and reproductive history do not affect bone mineral density among young women aged 19-25 years old [49].

This study has several limitations. First, statistical power to detect the difference in OSI values between calcium groups for each $\mathrm{Cdx} 2$ genotype is different because the number of subjects in each genotype group is not the same. Therefore, the relationship between calcium intake and OSI in each genotype should be interpreted with caution.

Second, we did not measure serum vitamin D concentrations, which is considered an important factor for bone health. Although meta-analysis suggested the relationship between serum vitamin $\mathrm{D}$ and fracture risk, the relationship between serum vitamin $\mathrm{D}$ concentrations and bone status in young Japanese women has not reached a consensus [40,50]. Moreover, some studies have reported no significant difference in serum vitamin $\mathrm{D}$ concentration between $\mathrm{Cdx} 2$ genotypes [16,29].

Third, the validation of calcium intake assessed by FFQg was reported only for crude values (mg/day) and not according to the density method (mg/1000 kcal) [21]. Moreover, the validity was confirmed by the correlation coefficient [21], and the validity of the absolute quantitative value remained unclear. Therefore, we used calcium intake to categorize participants to reduce the effect of measurement error, while categorized calcium intake was used as a categorical independent variable for ANCOVA.

Fourth, some residual confounding may exist. BMI was calculated from self-reported height and weight. The previous study suggested systematic bias in self-reporting height and weight values [51]. Therefore, some subjects, especially those with obesity, may underreport their weight and then the respective BMI values might be inaccurate. Moreover, the questionnaire regarding physical activity habits was not validated. Although the proportion of subjects who referred physical activity habits almost match the results of a survey made by the Japan Sports Agency published in 2016 [52], we cannot entirely rule out the possibility of misclassification.

Finally, we assessed only the calcaneus using the QUS method as an index of peak bone mass. Although a previous study reported the values assessed by the QUS method significantly correlate to those assessed by DXA on other bone sites [53], future studies using additional bone sites are required to ascertain whether the genotype difference in the effect of calcium intake on peak bone mass exists elsewhere.

\section{Conclusions}

This study, conducted in a narrow-aged young Japanese women cohort, suggests that the relationship between dietary calcium intake and peak bone mass is affected by Cdx2 genotypes. A homogeneous population can be an effective way to reduce confounding and to detect functional relationships. However, generalizability to the entire population is limited. Further genetics-based studies, focused on the effects of nutrients on peak bone mass, in various homogeneous populations are required to increase peak bone mass more effectively.

Author Contributions: Conceptualization, Y.S., Y.T. and K.I.; methodology, F.O., Y.S., H.M.-A. and K.I.; formal analysis, F.O. and Y.S.; investigation, F.O., Y.S. and Y.T.; resources, Y.S., Y.T. and K.I.; data curation, F.O. and Y.S.; writing-original draft preparation, F.O.; writing-review and editing, Y.S., H.M.-A. and K.I.; visualization, F.O. and Y.S.; supervision, Y.T. and K.I.; project administration, Y.S., Y.T. and K.I.; funding acquisition, Y.S. and Y.T. All authors have read and agreed to the published version of the manuscript.

Funding: This research was funded in part by grants-in-aid for Scientific Research (grant no. 18K17938) from the Ministry of Education, Culture, Sports, Science and Technology of Japan, and the Comprehensive Research Project, Research Institute of Domestic Science, Tokyo Kasei University. 
Acknowledgments: We would like to thank Editage (www.editage.com) for English language editing.

Conflicts of Interest: The authors declare no conflict of interest.

\section{References}

1. Pérez-López, F.R.; Chedraui, P.; Cuadros-López, J.L. Bone mass gain during puberty and adolescence: Deconstructing gender characteristics. Curr. Med. Chem. 2010, 17, 453-466. [CrossRef] [PubMed]

2. Zhang, H.C.; Kushida, K.; Atsumi, K.; Kin, K.; Nagano, A. Effects of age and menopause on spinal bone mineral density in Japanese women: A ten-year prospective study. Calcif. Tissue Int. 2002, 70, 153-157. [CrossRef] [PubMed]

3. Bonjour, J.-P.; Chevalley, T.; Ferrari, S.; Rizzoli, R. The importance and relevance of peak bone mass in the prevalence of osteoporosis. Salud Publica Mex. 2009, 51, S5-S17. [CrossRef] [PubMed]

4. Weaver, C.M.; Gordon, C.M.; Janz, K.F.; Kalkwarf, H.J.; Lappe, J.M.; Lewis, R.; O’Karma, M.; Wallace, T.C.; Zemel, B.S. The National Osteoporosis Foundation's position statement on peak bone mass development and lifestyle factors: A systematic review and implementation recommendations. Osteoporos. Int. 2016, 27, 1281-1386. [CrossRef] [PubMed]

5. Miyabara, Y.; Onoe, Y.; Harada, A.; Kuroda, T.; Sasaki, S.; Ohta, H. Effect of physical activity and nutrition on bone mineral density in young Japanese women. J. Bone Miner. Metab. 2007, 25, 414-418. [CrossRef]

6. Davies, J.H.; Evans, B.A.J.; Gregory, J.W. Bone mass acquisition in healthy children. Arch. Dis. Child. 2005, 90, 373-378. [CrossRef]

7. Rizzoli, R.; Bianchi, M.L.; Garabédian, M.; McKay, H.A.; Moreno, L.A. Maximizing bone mineral mass gain during growth for the prevention of fractures in the adolescents and the elderly. Bone 2010, 46, 294-305. [CrossRef]

8. Welten, D.; Kemper, H.; Post, G.; Van Staveren, W. A meta-analysis of the effect of calcium intake on bone mass in young and middle-aged females and males. Osteoporos. Int. 1996, 6, 111. [CrossRef]

9. Huncharek, M.; Muscat, J.; Kupelnick, B. Impact of dairy products and dietary calcium on bone-mineral content in children: Results of a meta-analysis. Bone 2008, 43, 312-321. [CrossRef]

10. Tai, V.; Leung, W.; Grey, A.; Reid, I.R.; Bolland, M.J. Calcium intake and bone mineral density: Systematic review and meta-analysis. BMJ 2015, 351, h4183. [CrossRef]

11. Eisman, J.A. Genetics, calcium intake and osteoporosis. Proc. Nutr. Soc. 1998, 57, 187-193. [CrossRef]

12. Cusack, S.; Cashman, K.D. Impact of genetic variation on metabolic response of bone to diet. Proc. Nutr. Soc. 2003, 62, 901-912. [CrossRef]

13. Arai, H.; Miyamoto, K.I.; Yoshida, M.; Yamamoto, H.; Taketani, Y.; Morita, K.; Kubota, M.; Yoshida, S.; Ikeda, M.; Watabe, F.; et al. The polymorphism in the caudal-related homeodomain protein Cdx-2 binding element in the human vitamin D receptor gene. J. Bone Miner. Res. 2001, 16, 1256-1264. [CrossRef]

14. Stathopoulou, M.G.; Dedoussis, G.V.Z.; Trovas, G.; Theodoraki, E.V.; Katsalira, A.; Dontas, I.A.; Hammond, N.; Deloukas, P.; Lyritis, G.P. The role of vitamin D receptor gene polymorphisms in the bone mineral density of Greek postmenopausal women with low calcium intake. J. Nutr. Biochem. 2011, 22, 752-757. [CrossRef]

15. Esterle, L.; Jehan, F.; Sabatier, J.P.; Garabedian, M. Higher milk requirements for bone mineral accrual in adolescent girls bearing specific Caucasian genotypes in the VDR promoter. J. Bone Miner. Res. 2009, 24, 1389-1397. [CrossRef]

16. Macdonald, H.M.; McGuigan, F.E.; Stewart, A.; Black, A.J.; Fraser, W.D.; Ralston, S.; Reid, D.M. Large-scale population-based study shows no evidence of association between common polymorphism of the VDR gene and BMD in British women. J. Bone Miner. Res. 2006, 21, 151-162. [CrossRef]

17. Morita, A.; Iki, M.; Dohi, Y.; Ikeda, Y.; Kagamimori, S.; Kagawa, Y.; Yoneshima, H. Effects of the Cdx-2 polymorphism of the vitamin $\mathrm{D}$ receptor gene and lifestyle factors on bone mineral density in a representative sample of Japanese women: The Japanese Population-based Osteoporosis (JPOS) Study. Calcif. Tissue Int. 2005, 77, 339-347. [CrossRef]

18. Uitterlinden, A.G.; Fang, Y.; Bergink, A.P.; Van Meurs, J.B.; Van Leeuwen, H.P.; Pols, H.A. The role of vitamin D receptor gene polymorphisms in bone biology. Mol. Cell. Endocrinol. 2002, 197, 15-21. [CrossRef]

19. Ministry of Health; Labour and Welfare. Dietary Reference Intakes for Japanese, 2015; Daiichi Shuppan Publishing Co., Ltd.: Tokyo, Japan, 2014. (In Japanese) 
20. Takahashi, K.; Yoshimura, Y.; Kaimoto, T.; Kunii, D.; Komatsu, T.; Yamamoto, S. Validation of a Food Frequency Qustionnaire Based on Food Groups for Estimating Individual Nutrient Intake. Jpn. J. Nutr. Diet. 2001, 59, 221-232. (In Japanese) [CrossRef]

21. Takahashi, K. Food Frequency Questionnaire Based on Food Groups for Estimating Individual Nutrient Intake. Jpn. J. Nutr. Diet. 2003, 61, 161-169. (In Japanese) [CrossRef]

22. Greenspan, S.L.; Bouxsein, M.L.; Melton, M.E.; Kolodny, A.H.; Clair, J.H.; Delucca, P.T.; Stek, M.; Faulkner, K.G.; Orwoll, E.S. Precision and Discriminatory Ability of Calcaneal Bone Assessment Technologies. J. Bone Miner. Res. 1997, 12, 1303-1313. [CrossRef]

23. Hans, D.; Dargent-Molina, P.; Schott, A.M.; Sebert, J.L.; Cormier, C.; Kotzki, P.O.; Delmas, P.D.; Pouilles, J.M.; Breart, G.; Meunier, P.J. Ulrasonographic heel measurements to predict hip fracture in elderly women: The EPIDOS prospective study. Lancet 1996, 348, 511-514. [CrossRef]

24. Moayyeri, A.; Adams, J.E.; Adler, R.A.; Krieg, M.A.; Hans, D.; Compston, J.; Lewiecki, E.M. Quantitative ultrasound of the heel and fracture risk assessment: An updated meta-analysis. Osteoporos. Int. 2012, 23, 143-153. [CrossRef]

25. Tsuda-Futami, E.; Hans, D.; Njeh, C.F.; Fuerst, T.; Fan, B.; Li, J.; He, Y.Q.; Genant, H.K. An evaluation of a new gel-coupled ultrasound device for the quantitative assessment of bone. Br. J. Radiol. 1999, 72, 691-700. [CrossRef]

26. Hara, S.; Yanagi, H.; Amagai, H.; Endoh, K.; Tsuchiya, S.; Tomura, S. Effect of physical activity during teenage. Calcif. Tissue Int. 2001, 68, 23-30. [CrossRef]

27. Sasaki, M.; Harata, S.; Kumazawa, Y.; Mita, R.; Kida, K.; Tsuge, M. Bone mineral density and osteo sono assessment index in adolescents. J. Orthop. Sci. 2000, 5, 185-191. [CrossRef]

28. Marozik, P.M.; Tamulaitiene, M.; Rudenka, E.; Alekna, V.; Mosse, I.; Rudenka, A.; Samokhovec, V.; Kobets, K. Association of Vitamin D receptor gene variation with osteoporosis risk in Belarusian and Lithuanian postmenopausal women. Front. Endocrinol. (Lausanne) 2018, 9, 305. [CrossRef]

29. Taha, I.M.; Allah, A.M.A.; El Tarhouny, S. Association of Vitamin D Gene Polymorphisms and Bone Mineral Density in Healthy young Saudi Females. Curr. Mol. Med. 2019, 19, 196-205. [CrossRef]

30. Fang, Y.; Van Meurs, J.B.; Bergink, A.P.; Hofman, A.; Van Duijn, C.M.; Van Leeuwen, J.P.; Pols, H.A.; Uitterlinden, A.G. Cdx-2 polymorphism in the promoter region of the human vitamin D receptor gene determines susceptibility to fracture in the elderly. J. Bone Miner. Res. 2003, 18, 1632-1641. [CrossRef]

31. Gentil, P.; Lima, R.M.; Lins, T.C.L.; Abreu, B.S.; Pereira, R.W.; Oliveira, R.J. Physical activity, Cdx-2 genotype, and BMD. Int. J. Sports Med. 2007, 28, 1065-1069. [CrossRef]

32. Gu, J.M.; Xiao, W.J.; He, J.W.; Zhang, H.; Hu, W.W.; Hu, Y.Q.; Li, M.; Liu, Y.J.; Fu, W.Z.; Yu, J.B.; et al. Association between VDR and ESR1 gene polymorphisms with bone and obesity phenotypes in Chinese male nuclear families. Acta Pharmacol. Sin. 2009, 30, 1634-1642. [CrossRef]

33. Marozik, P.; Mosse, I.; Alekna, V.; Rudenko, E.; Tamulaitiene, M.; Ramanau, H.; Strazdiene, V.; Samokhovec, V.; Ameliyanovich, M.; Byshnev, N.; et al. Association between polymorphisms of VDR, COL1A1, and LCT genes and bone mineral density in belarusian women with severe postmenopausal osteoporosis. Medicina 2013, 49, 177-184. [CrossRef]

34. Rojano-Mejía, D.; Coral-Vázquez, R.M.; Coronel, A.; Cortes-Espinosa, L.; del Carmen Aguirre-García, M.; Valencia-Villalvazo, E.Y.; Canto, P. Relation of the estrogen receptor and vitamin D receptor polymorphisms with bone mineral density in postmenopausal Mexican-mestizo women. Gene 2014, 537, 10-14. [CrossRef]

35. Martinaityte, I.; Jorde, R.; Emaus, N.; Eggen, A.E.; Joakimsen, R.M.; Kamycheva, E. Bone mineral density is associated with Vitamin D related rs6013897 and estrogen receptor polymorphism rs4870044: The Tromsø study. PLoS ONE 2017, 12, 1-12. [CrossRef]

36. Mencej-Bedrač, S.; Preželi, J.; Kocjan, T.; Teskač, K.; Ostanek, B.; Šmelcer, M.; Marc, J. The combinations of polymorphisms in vitamin D receptor, osteoprotegerin and tumour necrosis factor superfamily member 11 genes are associated with bone mineral density. J. Mol. Endocrinol. 2009, 42, 239-247. [CrossRef]

37. Ling, Y.; Lin, H.; Aleteng, Q.; Ma, H.; Pan, B.; Gao, J.; Gao, X. Cdx-2 polymorphism in Vitamin D Receptor gene was associated with serum 25-hydroxyvitamin D levels, bone mineral density and fracture in middle-aged and elderly Chinese women. Mol. Cell. Endocrinol. 2016, 427, 155-161. [CrossRef]

38. Sasaki, S.; Yanagibori, R. Association between current nutrient intakes and bone mineral density at calcaneus in pre- and postmenopausal Japanese women. J. Nutr. Sci. Vitaminol. (Tokyo) 2001, 47, 289-294. [CrossRef] 
39. Tylavsky, F.A.; Anderson, J.J.; Talmage, R.V.; Taft, T.N. Are calcium intakes and physical activity patterns during adolescence related to radial bone mass of white college-age females? Osteoporos. Int. 1992, 2, 232-240. [CrossRef]

40. Ito, S.; Ishida, H.; Uenishi, K.; Murakami, K.; Sasaki, S. The relationship between habitual dietary phosphorus and calcium intake, and bone mineral density in young Japanese women: A cross-sectional study. Asia Pac. J. Clin. Nutr. 2011, 20, 411-417.

41. Lee, K.J.; Kim, K.S.; Kim, H.N.; Seo, J.A.; Song, S.W. Association between dietary calcium and phosphorus intakes, dietary calcium/phosphorus ratio and bone mass in the Korean population. Nutr. J. 2014, 13, 114. [CrossRef]

42. Joo, N.S.; Dawson-Hughes, B.; Yeum, K.J. 25-Hydroxyvitamin D, calcium intake, and bone mineral content in adolescents and young adults: Analysis of the fourth and fifth Korea National Health and Nutrition Examination Survey (KNHANES IV-2, 3, 2008-2009 and V-1, 2010). J. Clin. Endocrinol. Metab. 2013, 98, 3627-3636. [CrossRef]

43. Correa-Rodríguez, M.; Rio-Valle, J.S.; González-Jiménez, E.; Rueda-Medina, B. The Effects of Body Composition, Dietary Intake, and Physical Activity on Calcaneus Quantitative Ultrasound in Spanish Young Adults. Biol. Res. Nurs. 2016, 18, 439-444. [CrossRef]

44. Hernandez, C.J.; Beaupré, G.S.; Carter, D.R. A theoretical analysis of the relative influences of peak BMD, age-related bone loss and menopause on the development of osteoporosis. Osteoporos. Int. 2003, 14, 843-847. [CrossRef]

45. Chang, B.; Schlussel, Y.; Sukumar, D.; Schneider, S.H.; Shapses, S.A. Influence of vitamin D and estrogen receptor gene polymorphisms on calcium absorption: BsmI predicts a greater decrease during energy restriction. Bone 2015, 81, 138-144. [CrossRef]

46. Dawson-Hughes, B.; Harris, S.S.; Finneran, S. Calcium absorption on high and low calcium intakes in relation to vitamin D receptor genotype. J. Clin. Endocrinol. Metab. 1995, 80, 3657-3661.

47. Rowland, G.W.; Schwartz, G.G.; John, E.M.; Ingles, S.A. Protective effects of low calcium intake and low calcium absorption vitamin D receptor genotype in the California collaborative prostate cancer study. Cancer Epidemiol. Biomark. Prev. 2013, 22, 16-24. [CrossRef]

48. Rowland, G.W.; Schwartz, G.G.; John, E.M.; Ingles, S.A. Calcium intake and prostate cancer among African Americans: Effect modification by vitamin D receptor calcium absorption genotype. J. Bone Miner. Res. 2012, 27, 187-194. [CrossRef]

49. Hirota, T.; Nara, M.; Ohguri, M.; Manago, E.; Hirota, K. Effect of diet and lifestyle on bone mass in Asian young women. Am. J. Clin. Nutr. 1992, 55, 1168-1173. [CrossRef]

50. Nakamura, K.; Nashimoto, M.; Matsuyama, S.; Yamamoto, M. Low serum concentrations of 25-hydroxyvitamin D in young adult Japanese women: A cross sectional study. Nutrition 2001, 17, 921-925. [CrossRef]

51. Stommel, M.; Schoenborn, C.A. Accuracy and usefulness of BMI measures based on self-reported weight and height: Findings from the NHANES \& NHIS 2001-2006. BMC Public Health 2009, 9, 421.

52. Public Opinion Survey on Sports Participation and Its Peripheral Situation (from November to December 2017 Survey Made by Japan Sports Agency). Available online: https://www.mext.go.jp/prev_sports/comp/b_ menu/other/_icsFiles/afieldfile/2017/02/15/1382031_001.pdf (accessed on 31 December 2019). (In Japanese)

53. Duquette, J.; Honeyman, T.; Hoffman, A.; Ahmadi, S.; Baran, D. Effect of bovine bone constituents on broadband ultrasound attenuation measurements. Bone 1997, 21, 289-294. [CrossRef]

(C) 2020 by the authors. Licensee MDPI, Basel, Switzerland. This article is an open access article distributed under the terms and conditions of the Creative Commons Attribution (CC BY) license (http://creativecommons.org/licenses/by/4.0/). 